\title{
Bartłomiej Cieśla
}

Uniwersytet Łódzki

\section{Poziomy kreatywności genologicznej}

Celem artykułu jest wskazanie na problem kreatywności genologicznej. Tok zasadniczej części wywodu wyznaczać będą odpowiedzi na trzy pytania, tj.: 1) co właściwie oznacza sformułowanie kreatywność genologiczna? 2) które poziomy wzorca gatunkowego można wyzyskiwać w twórczy sposób? 3) jakie mogą być konkretne przejawy kreatywności $w$ obrębie jednego z aspektów wzorca?

Materiał, który wykorzystano do analizy, przejęty został z łódzkiej prasy humorystycznej okresu międzywojnia.

Nawiązując do słownikowych definicji1, można by wskazać, że kreatywność genologiczna to twórcze wyzyskanie wzorca organizacji tekstu. Z jednej strony ma charakter wewnętrznotekstowy, uobecnia się $w$ wypowiedzi na poziomie strukturalnym, stylistycznym, poznawczym i pragmatycznym (na jednym z nich lub kilku jednocześnie) ${ }^{2}$, z drugiej zaś stanowi koncept autora, zewnętrzny wobec konkretnej aktualizacji. Oznaczać może zabiegi podejmowane na wypowiedzi polegające na rozszerzaniu jej konwencjonalnej pojęciowo-formalnej struktury - $w$ tym sensie kreatywne jest to, co w stosunku do kanonicznej postaci wzorca okazuje się naddane a także wskazywać na każdy przejaw oryginalności, również tej, która obok innych parametrów decyduje o tożsamości danego gatunku.

1 W Słowniku wyrazów obcych pod red. J. Tokarskiego czytamy, że kreatywny to 'tworzący coś nowego lub oryginalnego; twórczy', ang. creative.

2 Aspekty, o których mowa, usystematyzowała Maria Wojtak w pracy Wzorce gatunkowe wypowiedzi a realizacje tekstowe, [w:] Polska genologialingwistyczna, red. R. Cudak i D. Ostaszewska, PWN, Warszawa 2008. 
Należy zaznaczyć, że kreatywność genologiczna to nie tylko immanentna własność wyłą cznie niektórych gatunków, ale też postawa wobec tekstu. Z tej perspektywy przyjąć trzeba, że każdy gatunek może stanowić oryginalną, przykuwającą uwagę performancję. Co prawda niektóre typy mowy ${ }^{3}$ sprzyjają twórczemu podejściu do budowania ich aktualizacji - gatunkami takimi niewątpliwie są esej, felieton czy powieść postmodernistyczna, dla których kreatywność jest kategorią prawie aprioryczną - niezależnie od tego wskazać można rodzaje tekstów, dla których oryginalność nie jest cechą konstytutywną, niekiedy wyjątkowo spetryfikowane, ale wyzyskiwane w szczególny sposób. Prasa humorystyczna stanowi dobitny tego przykład, por.:

[1] Ogłoszenie

Zginęła żona wagi 150 kilogramów. Znak szczególny: usta jej

się nie zamykają. Uczciwy znalazca zechce ją zatrzymać za odpowiedniem wynagrodzeniem.

[WB, 1934, nr 13, s. 4]

[2] Psy

Wieszam na bliźnich za darmo i na raty. Robota solidna i bezkonkurencyjna.

Poseł na Sejm.

[WMWŻ, 1929, nr 3, s. 5]

Tradycyjny (a więc nienacechowany humorystycznie) anons pełni funkcję informacyjną i nakłaniającą [Bańko 2006: 716], zwykle publikowany jest $w$ mediach (prasie, radiu, telewizji, internecie) lub eksponowany w miejscach publicznych. Jego główne własności to: krótka forma, zwięzłość i precyzja. W żartobliwych nawiązaniach realizowane są takie własności gatunku, jak skrótowość (najczęściej jednowypowiedzeniowość), podmiotowość (wyraźna $w$ formach pierwszej osoby czasowników), wyodrębnianie w nagłówkach słów-kluczy mających przykuć uwagę. Nietypowa

3 Wyrażenia typ mowy, rodzaj tekstu, model tekstowy wprowadzane są $w$ artykule jako synonimy terminu gatunek tekstu (wypowiedzi). 
jednak, bo podporządkowana komizmowi, jest ich treść. Najczęściej funkcję głównego środka stymulującego przebieg komiczny $w$ anonsie pełni dowcip językowy.

Opis przejawów kreatywności genologicznej wpisywany jest $w$ analizę większości gatunków, przede wszystkim literackich, retorycznych i prasowych. Wnioski dotyczące rozpiętości i granic typu mowy formułuje się na podstawie oglądu aktualizacji prototypowych i niekanonicznych, rozciągających $w$ pewnym stopniu konstrukcję danego gatunku. Te drugie bardzo często wiążą się z zamysłem oryginalnej kreacji. Należą do nich - zgodnie z typologią Marii Wojtak: wzorce alternacyjne - takie, które funkcjonuja jako rezultat przekształcania poszczególnych poziomów i aspektów wzorca kanonicznego, oraz wzorce adaptacyjne, czyli nawiqzania do obcych schematów gatunkowych [Wojtak 2008: 355-360]. Należy jednak podkreślić, że kanoniczność $w$ tym wymiarze nie jest synonimem sztampowości - wskazuje wyłącznie na tożsamość wzorca. Natura wielu gatunków naznaczona jest pierwiastkiem kreacji, a więc to, co oryginalne, nietypowe, paradoksalnie może być zupełnie zwyczajne. I przeciunie - nie można powiedzieć, że każde odejście od prototypu musi być kreatywne. Rozmaite alternacje mogą wiązać się przecież wyłącznie z nieznaczną modyfikacją podstawowej funkcji wypowiedzi lub eliminacją któregoś z typowych pięter formalnej konstrukcji. Zabiegi tego rodzaju trudno interpretować jako szczególnie twórcze.

Na oryginalność tekstowo-językową można wreszcie patrzeć jako na własność nie tylko konkretnej wypowiedzi, ale również grupy tekstów stanowiących trzon pewnego zbioru, np. czasopisma. W tym sensie oryginalne jest to, co przełamuje genologiczną niezmienność kolekcji. Taki rodzaj kreatywności można by uznać za doraźny, ujawniający się nie tyle $w$ drodze zestawiania różnych aktualizacji jednego wzorca gatunkowego, ile w wyniku frekwencyjnego porównania rodzajów wypowiedzi specyficznych dla określonego medium. W łódzkiej prasie posługiwanie się gatunkami humorystycznymi, prasowymi i użytkowymi, takimi jak m.in. anegdota, satyra, dowcip, humoreska, dowcip, wzmianka, notatka, felieton, sonda, ogłoszenie czy list, bywało uatrakcyjniane 
wypowiedziami zupełnie na tym tle peryferyjnymi, jak przegląd prasy, referencje czy kalendarium. Oczywiście tak pojmowana kreatywność bardzo często ma charakter wyłącznie pozorny. Teksty, które ze względu na ciekawy globalny koncept sprawiają wrażenie artystycznie intrygujących, przełamujących gatunkowy monolit danego tytułu, mogą być napisane słabo, por.:

[3]

„Szczęśliwy kochanek” 2000 metrów długości. Zachwyt wśród tłumów.

„Pocałunek kobiety”. Odbitka w kolorach.

„Dessous pani Pompadour". Nowoczesna wentylacja.

„W objęciach artystki”. Dla młodzieży wzbronione.

„Dziewczę z zaułka”. Dla wojskowych i bezrobotnych ulga.

Sensacja! Podwójny program! „Noc poślubna”, „W dziewi-

czych puszczach".

„Smutny koniec Don Juana”.

Pierwszorzędna orkiestra.

„Adam i Ewa” Film propagandowy Min. Skarbu.

[SMSŻ, 1931, nr 11, s. 5]

Aktualizacja razi pospolitością („Szczęśliwy kochanek” 2000 metrów długości. Zachwyt wśród tłumów; Sensacja! Podwójny program! „Noc poślubna”, „W dziewiczych puszczach”; „Dessous pani Pompadour". Nowoczesna wentylacja) i banalnością („Wobjęciach artystki". Dla młodzieży wzbronione). Ciekawy koncept polegający na zestawieniu kilku tytułów filmowych łączonych z komentarzem, a więc próba nadania wypowiedzi formy repertuaru kinowego, nie zostaje zrealizowany na dobrym poziomie ze względu na niską wartość odautorskich dopisków. Kreatywny zamysł nie idzie $w$ tym wypadku $w$ parze z twórczym wykonaniem.

Na koniec ogólnych rozważań trzeba też podkreślić, że percepcja wzorca gatunkowego może zmieniać się wraz z jego rozwojem. Kanoniczny wariant typu mowy, który zrazu bywał określany jako nowatorski, odkrywczy, wprowadzający świeżość w uniwersum tekstowym, z czasem może stracić swój szczególny status. Wydaje się, że dobrym tego przykładem jest powieść. Klasyczny model 
- dialogowy, prozatorski, z chronologiczną, wielowątkową fabułą i wszechwiedzącym narratorem - przez wielu krytyków i literatów uznany został za zużyty. Współcześnie bywa zastępowany wariantami bazującymi na autotematyzmie, intertekstualności, antymimetyzmie i formalnym eklektyzmie.

Kreatywność genologiczna tkwiąca $w$ danej aktualizacji tekstowej, jak już podkreślono, może być odczytana na każdym z poziomów wzorca: strukturalnym, stylistycznym, pragmatycznym i poznawczym - jednym lub kilku naraz.

\section{Kreatywność na poziomie wyłącznie strukturalnym}

Dobry przykład oryginalności na poziomie wyłącznie strukturalnym stanowią wzorce gatunkowe dające możliwość adaptacji innych typów mowy. Oczywiście tylko wtedy, gdy transfer taki wiąże się z powieleniem wyłącznie konwencjonalnych własności przejmowanego wzorca. Adaptacja urozmaica co prawda styl wypowiedzi „nadrzędnej”, sama w sobie nie stanowi jednak żadnej nowej jakości, wartej wyjątkowej uwagi. W łódzkiej prasie humorystycznej produktywnym gatunkiem „pasożytującym” na innych typach wypowiedzi była humoreska. Krótkie, prozatorskie opowiadanie pełniące funkcję humorystyczną, odznaczające się pogodnym sposobem ujmowania zjawisk, prostotą fabuły, bogactwem środków językowego kształtowania humoru, uatrakcyjniano transmisją innych, najczęściej miniaturowych, modeli tekstowych. Wiele z nich opierano na strukture epistolarnej.

Jednym ze sztandarowych tekstów „Wolnej Myśli - Wolnych Żartów” był tzw. „słownik etymologiczny”, czyli zbiór alfabetycznie grupowanych wyrazów, poddawanych reinterpretacji etymologicznej, polegającej na przypisaniu wyrazowi wtórnego znaczenia etymologicznego wskutek skojarzenia jego budowy z innym, formalnie podobnym słowem [Cienkowski 1972]. Reinterpretację, jako zjawisko o podłożu czysto strukturalnym, najłatwiej zaobserwować, analizując wyrazy obcego pochodzenia. To one, jako mniej 
przejrzyste, wywołują asocjacje umożliwiające przekształcenie ich znaczenia, np. wyraz goliat w gwarowym znaczeniu 'golec, biedak' czy leksem burak, pochodzący od łac. borrago, współcześnie łączony przez użytkowników języka z przymiotnikiem bury.

Oto jeden z licznych przykładów:

[4] Słownik etymologiczny

- Autokrata - automobilista w kozie

- Amoniak - synek bożka Ammon-Ra

- Afektacja - częste powtarzanie w rozmowie wykrzyknika:

"A fe!" (...)

- Bojowniczka - niewiasta zachwycająca się utworami

Boy'a (...)

- Cyrkiel - dyrektor cyrku

- Cyrkularz - amator cyrku (...)

- Demonstracja - podszepty demona (...)

- Elipsa - pieścić psa pani Eli (...)

- Flegmatyk - spluwający flegmą (...)

- Gagatek - subjekt konfekcyjny, z działu sprzedaży gatek

- Garbnik - posiadający garb

- Géślarz - pasący gęsi (...)

- Inkasent - członek starożytnego plemienia Inków

- ذałowy - ja, wybierający się na łowy (...)

- Karcić - grać w karty

- Kiełbasa - hodowla kiełbi (...)

- Łączyć - chodzić po łące

- Mamidło - gadatliwa mama

- Magnat - chudzielec, który nie ma ciała, tylko same gnaty (...)

- Odważnik - odważny mężczyzna (...)

- Poplecznik - owad spacerujący po plecach (...)

- Pisuar - to samo, co: pisarz (...)

- Transport - człowiek, który picie tranu uważa za sport (...)

- Wicuś - człowiek, który wi cuś, ale nie wie dobrze, co

- Zajadły - gość, płacący w restauracji za jadło

- Zażarty - pismo humorystyczne płacące kary za skonfi-

skowane żarty

- Żywica - kobieta posiadające żywe usposobienie

[WMWŻ, 1928, nr 28, s. 9] 
Kreatywność na poziomie wyłącznie strukturalnym widać również $w$ tekstach, których budowa rytmiczna odpowiada architektonice powszechnie kojarzonych $w$ międzywojniu piosenek. Ponieważ podstawa nawiązania zawsze wskazywana jest przed korpusem, czytelnik bez żadnego trudu odgaduje przyjęty koncept, sprawiający, że zupełnie świeża dla odbiorcy wypowiedź zaczyna „brzmieć” znajomo. Co więcej, konotacje, jakie wywołuje oryginał, przeniesione zostają częściowo na wtórną realizację. Oto jeden z przykładów:

[5] Gdy światła w latarniach zapłoną. (melodja Trink Bruderlein)

Gdy światła w latarniach zapłoną

W kawiarniach rozlegnie się gwar,

Niech troski dnia $w$ trunku zatoną,

Niech życia omota nas czar.

W szklenicach niech pieni się wino,

A w żyłach niech tętni nam krew.

Daj usta czerwone dziewczyno,

W świat echem niech płynie nasz śpiew.

Refren:

Pij, pij z kielicha pij, Rozkoszy błogiej sny śnij.

Pij, pij z czary do dna Niech obcą będzie ci łza Życie wszak tak jak ptak, Szybko przeleci nasz glob. Tu, czy tam, choćby sam, Niech pije pan, czy to chłop (...)

[WMWŻ, 1929, nr 12, s. 6]
Tekst oryginału:

Das Trinken, das soll man nicht lassen, Das Trinken regiert doch die Welt, Man soll auch den Menschen nicht hassen, Der stehts eine Lage bestellt. Ob Bier oder Wein, ob Champagner, Nur laßt uns beim Trinken nicht prahlen,' Es trank den Champagner schon mancher, Und konnt ihn nachher nicht bezahlen.

Trink, trink, Brüderlein trink, Laß doch die Sorgen zu Haus!

Trink, trink, Brüderlein trink, Zieh doch die Stirn nicht so kraus

Meide den Kummer und meide den Schmerz, Dann ist das Leben ein Scherz! 
Wypowiedź cytowana z "Wolnych Żartów” i tekst piosenki co prawda różnią się między sobą, utrzymane są jednak $w$ takiej samej - pogodnej, nieco też melancholijnej - konwencji. Ukształtowanie stukturalnorytmiczne wzorca stylizacyjnego nie jest zupełnie tożsame z budową polskojęzycznej przeróbki - nie przeszkadza to jednak, by wyśpiewać ją w proponowany przez autora sposób. Trudno $w$ tym wypadku mówić o kreatywności na poziomie stylistycznym. Tekst ma charakter prostej rymowanki nawiązującej pod względem składniowym i leksykalnym do niemieckiej piosenki.

\section{Kreatywność na poziomie wyłącznie stylistycznym}

Jest to najczęstszy rodzaj autonomicznie występującej kreatywności, najszybciej zauważalny i powszechnie najwyżej wartościowany. W lokalnej prasie humorystycznej - pomijając bogactwo technik dowcipu językowego - realizowany za sprawą jakościowo różnych stylizacji, głównie potocyzacji i dialektyzacji. Łódzcy twórcy często stylizują fragmenty tekstów na język cudzoziemców. Oto jeden z przykładów:

[6] Łgarz

- Panie Hosenknopf, pan jesteś skończony łgarz i oscercarz.

- Panie Szpinak, ja spitam panu dlaczego?

- Mówił pan, że moja żona szedży w gabinetu z moim

wspólnikiem. No nie?

- Mówiłem. Czy to prawda?

- Poleczałem, zobaczyłem... Łżesz pan. To wcale nie mój wspólnik.

- Do interesu to może nie, ale co dotykać żony, to chiba tak. [WMWŻ, 1929, nr 24 s. 3]

Rzeczona stylizacja nawiązuje do polszczyzny Żydów [Kamińska 1991: 77-81]. Wskazują na to pewne cechy językowe:

- z zakresu fonetyki:

a) mieszanie głosek szeregu zębowego, dziąsłowego i środkowojęzykowych: oscercarz, szedży, poleczałem; 
b) zastępowanie głoski y dźwiękiem i, np. spitam, chiba;

- z zakresu składni, np. spitam panu zam. spitam pana, w gabinetu zam. w gabinecie;

- z zakresu słowotwórstwa, np. oscercar, zam. oszczerca. Błędna forma utworzona za pomocą formantu - arz, na wzór nazw oznaczających wykonawców czynności;

- z zakresu leksyki, np. spójnik co zamiast aby (ew. coby).

\section{Kreatywność na poziomie wyłącznie pragmatycznym}

Ten rodzaj twórczego podejścia do tekstu egzemplifikują anonse, których autorzy nie sięgają po dowcip językowy ani nie kreują osobliwej wizji rzeczywistości. Własności strukturalne omawianych wypowiedzi upodabniają je do tradycyjnych anonsów drukowanych $w$ informacyjnej prasie międzywojennej. Różnica między kanoniczną wersją ogłoszenia a realizacjami, o których mowa, dotyczy intencji komunikacyjnej - celem humorysty staje się nie tyle przekazanie informacji, powiadomienie odbiorcy o możliwości nabycia jakiegoś towaru lub skorzystania z jakiejś usługi, ile uwydatnienie pewnego obrazu. Oto dwa przykłady z „Wolnych Żartów”:

[7] „Ogłoszenia”

(...) Potrzeba 100 wagonów papieru gazetowego dla pism codziennych, do czasu ukształtowania nowego rządu. Oferty: pisma codzienne $w$ Warszawie i $w$ Łodzi.

[WMWŻ, 1922, nr 9, s. 7]

[8] Znalazłem!

wydawcę, który regularnie płaci honorarjum. Oglądać można $w$ muzeum osobliwości!

[WMWŻ, 1929, nr 16, s. 6]

W obu tekstach nadawca wskazuje na preciwności wiążące się z funkcjonowaniem krajowego rynku wydawniczego: dekretowanie przez władzę ilości papieru przeznaczanego dla wydawców 
prasy oraz ich mizerną sytuację finansową. W drugim tekście co prawda zwracają uwage czytelnika pewne stylistyczne cechy obce ogłoszeniom (czas przeszły, ekspresyjność), nie są to jednak zabiegi, które można by traktować jako twórcze.

Humorystyczno-satyryczny ton obu wypowiedzi zostaje wyeksponowany na skutek zmiany tradycyjnego kontekstu życiowego ogłoszeń oraz ich prymarnej funkcji. Miniaturowa forma tekstów sprawia, że uwaga czytelników skupiona zostaje na komentarach.

\section{Kreatywność na poziomie wyłącznie poznawczym}

Z tym rodzajem kreatywności językowej mamy do czynienia wówczas, gdy autor w twórczy sposób wyzyskuje pewien konkretny obraz rzeczywistości, który nie musi być zniekształcony czy przejaskrawiony - może odpowiadać realnemu stanowi, powinien jednak, sam przez się koncentrować na sobie uwagę odbiorcy. Teksty takie mają charakter demaskatorski, np.:

[9] Temida

Recz dzieje się przed sądem we Frankfurcie. Sędzia zuraca

się do oskarżonego:

- Imię?

- Mojżesz.

- Dwa lata więzienia!... Nazwisko?

- Pinkeles.

- Trzy lata pozbawienia praw obywatelskich!... Miejsce urodzenia?

- Częstochowa.

- ... o tysiąc marek grzywny!

[Szp., 1939, nr 21, s. 5]

Dowcip piętnuje prześladowanie społeczności żydowskiej $w$ hitlerowskich Niemczech. Przedwojenne „Szpilki” na tle wszystkich gazet humorystycznych wydawanych w międzywojniu jawiły 
się jako największy antagonista niemieckiego dyktatora i faszyzmu. Obraz rzeczywistości przedstawiony w dowcipie powielany był $w$ wielu tekstach, najczęściej jednak scalany z innymi postaciami słownej oryginalności.

Za inny przykład kreatywności zachodzącej wyłącznie na poziomie poznawczym posłużyć mogą trawestacje dwóch znanych bajek Ignacego Krasickiego:

TRAWESTACJA

[10] Ptaszki w klatce.

- Czego płaczesz? staremu mówił złodziej młody.

Masz teraz lepsze $w$ klatce niż w polu wygody.

- Właśnie, właśnie, rzekł stary - głupstwo ci wybaczę,

Mają wkrótce mnie zwolnić i - dlatego płaczę.

[SMSŻ, 1931, nr 2, s. 3]
ORYGINAt

Ptaszki w klatce.

„Czegóż płaczesz? staremu mówił czyżyk młody -

Masz teraz lepsze $w$ klatce niż w polu wygody".

„Tyś w niej zrodzon - rzekł stary - przeto ci wybaczę;

Jam był wolny, dziś $w$ klatce - i dlatego płaczę".

Posługując się przeróbką, autor zuraca uwagę na iluzoryczność kary więziennej. Celnie diagnozuje problem podejmowany również współcześnie: czy warunki panujące $w$ zamknięciu odpowiadają represyjnej i wychowawczej funkcji izolacji? Aktualizacja ma wyraźnie charakter satyryczny - funkcja ta mieści się jednak w granicach gatunku bajki. Trudno mówić tu o kreatywności na poziomie stylistycznym ze względu na językową wtórność humorystycznej wypowiedzi wobec pierwowzoru. 


\section{Kreatywność na kilku poziomach organizacji tekstu}

Szeroki ogląd wypowiedzi publikowanych $w$ łódzkiej prasie dowodzi, że w znacznej większości kreatywność językowa w tekstach humorystycznych jest realizowana na dwóch lub trzech poziomach jednocześnie. Rzadko - na wszystkich.

Za przykład oryginalności na poziomie strukturalnym i stylistycznym posłużyć może humoreska, której korpus wzbogacono o adaptację ogłoszenia:

[11] Hotel sportowy „Rekord” w pobliżu miasteczka X. Przy powłoce śnieżnej ponad 90 centymetrów wysokości świetna okazja do uprawiania wszelkiego rodzaju sportów zimowych. Wszystkich zwolenników sportu zaprasza uprzejmie właściciel hotelu sportowego „Rekord” Alojzy Górka

[CzK, 1932, nr 6, s. 4]

Główny bohater, zapalony miłośnik sportów zimowych, natychmiast wyrusza $w$ podróż do niebywale zaśnieżonego kurortu, by na miejscu przekonać się o perswazyjnej sile reklamy. Informacja o tym, że przy powłoce śnieżnej ponad 90 centymetrów wysokości [jest] świetna okazja do uprawiania wszelkiego rodzaju sportów zimowych, okazuje się wyłącznie stwierdzeniem in genere, nieznajdującym odbicia $w$ rzeczywistych warunkach, jakie zastaje bohater: błoto sięga do kostek, a śniegu jest jak na lekarstwo. Umieszczenie cytowanego wypowiedzenia tuż za nagłówkiem wskazującym na ośrodek wypoczynkowy mylnie sugeruje, jakoby opisywane warunki panowały w pobliżu reklamowanego hotelu.

Oryginalność na poziomie pragmatycznym i poznawczym egzemplifikują wypowiedzi quasi-dziennikarskie, przybierające postać wzmianek i notatek prasowych, pisane stylem przezroczystym, nieprzykuwającym uwagi czytelnika, np. 
[12] Komunikat

W dniu wczorajszym rozpoczęły się rokowania sowiecko-japońskie, mające na celu zlikwidowanie kwestii spornych w związku z rybołówstwem na morzu Beringa. Zestrzelono siedemnaście samolotów.

[Szp., 1939, nr 24, s. 3]

W przytoczonej wypowiedzi zmianie ulega kanoniczna funkcja wzmianki prasowej. Gatunki informacyjne adaptowane na potrzeby prasy humorystycznej zawsze zyskują status wypowiedzi komicznych, muszą bowiem realizować globalną intencję całego tytułu. Jeśli uda się skutecznie wyzyskać określony wzorzec gatunkowy w zgoła innej niż tradycyjna funkcji - a tym samym efektywnie dokona się zmiany jego kontekstu życiowego - niewątpliwie mówić można o kreatywności. Autor tekstu bawi się również, modyfikując obraz świata. Pokój, zgodnie z tradycyjną konceptualizacją rzeczywistości, to czas bez wojen. Treści eksponowanej we wstępie nie odpowiada więc zakończenie, uruchamiające przebieg komiczny.

Chyba najczęściej scala się przejawy kreatywności pragmatycznej i stylistycznej, por.

[13]

TOKIO: Profesor tutejszego uniwersytetu odkrył rewelacyjny związek chemiczny. Jest to mianowicie: dwukapuścian grochu.

HOLLYWOOD: Jeden z dyrektorów słynnej wytwórni filmowej „Metro, Goldwyn Meyer” pan Meyer, w ostatnich dniach zapadł na zdrowiu. Onegdaj p. Meyer oznajmił rodzinie, że już nie czuje nóg. Wtedy przerażona rodzina zwołała konsyljum, mniemając, że już nadchodzi kres życia szanowanego filmowca, bowiem wszyscy zebrani czuli nogi p. Meyera zupełnie wyraźnie...

[WMWŻ, 1929, nr 1, s. 4] 
W tym wypadku zmiana kontekstu życiowego wzmianki idzie $w$ parze ze swoistą formą ukształtowania tekstu: neologią i defrazeologizacją.

Liczne są przykłady twórczego kształtowania trzech poziomów wzorca gatunkowego, np.

[14] Poradnik lekarski.

Ratowanie w wypadkach połknięcia monet.

Często się zdarza, że dzieci (bez względu na to, czy są ślubne, czy nieślubne) połykają przez nieostrożność różne twarde przedmioty, jak szpilki, guziki, gwoździe, pieniądze etc.

Ponieważ taki wypadek może się czasem skończyć bardzo nieprzyjemnie - to znaczy śmiercią, więc szybki ratunek jest więcej niż pożądany.

Dlatego też, gdy dziecko połyka monetę np. dwuzłotową, matka winna czemprędzej zawezwać p. Grabskiego, min. skarbu.

Radzę dlatego p. Grabskiego, a nie któregoś z lekarzy, gdyż metody lekarskie nie są takie pewne jak metody p. ministra skarbu.

Lekarz musiałby zrobić operację żołądka, ciąć, pompować, wycinać, a p. Grabski robi to o wiele prościej i bez bólu.

Gdy p. Grabski dowie się, że w żołądku dziecka znajduje się dwa złote, wtedy 50 procent wyciąga tytułem podatku obrotowego, 30 procent - majątkowego, 10 procent - przemysłowego, 10 proc. - mieszkaniowego, razem 2 złote i tak bez żadnej operacji dziecko już niema dwóch złotych w żołądku. [CzK, 1925, nr 5, s. 4]

Autor tekstu posługuje się techniką tzw. urealnionego absurdu. Niedorzeczny koncept uwiarygodniany jest przez inicjalny komponent ramy tekstowej (poradnik lekarski) i pierwsze dwa akapity wypowiedzi, wskazujące na przedmiot porady. Zestawienie dwóch porządków, realnego i absurdalnego (pomysł jakoby minister Grabski był w stanie pomóc choremu dziecku) uruchamiają przebieg komiczny. Językowym zwornikiem obu skryptów jest dowcip polisemiczny (słowo wyciagać użyte w dwóch znaczeniach 'ciągnąc, wydobywać, wyjmować skąd, z czego' [SDor.] i 'zabrać, 
wyłudzić'). Nietypowy dla porady prasowej wydaje się główny cel wypowiedzi związany z dezawuowaniem polityki pieniężnej ówczesnego ministra finansów. Nadawca prototypowej aktualizacji to przede wszystkim ekspert $w$ zakresie dziedziny, z której udziela wskazówek. Emitent cytowanej wypowiedzi zakłada dodatkowo maskę satyryka.

Kreatywność genologiczna, rozumiana jako wartość konkretnej wypowiedzi - jak dowodzą zebrane przykłady - może zostać zrealizowana na każdym poziomie wzorca gatunkowego.

W wypowiedziach humorystycznych najczęstsze są przykłady tzw. kreatywności stylistycznej, tworzonej za sprawą rozmaitych technik dowcipu słownego, w większości wypadków - bazujących na leksyce. Równie często kreatywność scalać może dwa lub trzy piętra semantyczno-formalnej struktury gatunku (liczne są przykłady twórczego wyzyskania wzorca na poziomach pragmatycznym i stylistycznym, a także pragmatycznym i poznawczym). Sporadycznie zaobserwować można przypadki twórczego podejścia do wszystkich poziomów naraz (co wynika zapewne z ograniczonych możliwości zabawy architektoniką wypowiedzi). Rzadkie są również przypadki kreatywności wyłącznie na poziomach pragmatycznym, poznawczym i strukturalnym (co wiąże się z faktem, że badane teksty humorystyczne oddziałują zazwyczaj na czytelnika żartem słownym o charakterze swoiście językowym, a więc kluczową rolę odgrywa w nich poziom stylistyczny).

Badania pokazują również, że o sile przebiegu komicznego nie decyduje liczba jakościowo różnych chwytów, lecz ich skuteczność. W tym sensie teksty, w których obserwujemy wyłącznie przejawy kreatywności na poziomie stylistycznym, pod względem humorystycznym mogą wydawać się atrakcyjniejsze od wypowiedzi łączących wszystkie cztery typy modyfikacji.

Warto zwrócić uwage, że każdy wzorzec gatunkowy przejawia pewne tendencje do modyfikowania go w określonym kierunku. Zabawa aktualizacją wzorca gatunkowego na którymkolwiek poziomie, jeśli nie ma charakteru akcydentalnego, może decydować o jego tożsamości i powinna być włączana do systematycznego opisu. 
Na marginesie zebranych $w$ artykule uwag należy podkreślić, że przeprowadzona analiza miała charakter wyłącznie oglądowy. W praktyce bowiem twórczo napisane wypowiedzi kumulują najczęściej różne aspekty oryginalności, wzajemnie powiązane i uwarunkowane. Co więcej kreatywność jest kategorią subiektywną, a więc neutralna (obiektywna) ocena konkretnego tekstu ze względu na liczbę konstytuujących go „kreatywnych pięter” nastręcza poważnych trudności.

\section{Bibliografia}

Bańko M. [2006] Polszczyzna na co dzień, PW N, Warszawa.

Cienkowski W. [1972], Teoria etymologii ludowej, PWN, Warszawa.

Kamińska M. [1991], Stylizacja na polszczyznę Żydów w łódzkich tekstach mówionych, „Prace Językoznawcze”, T. 19: Studia polonistyczne, Katowice.

Wojtak M. [2008], Wzorce gatunkowe wypowiedzi a realizacje tekstowe, [w:] Polska genologia lingwistyczna, Cudak R., Ostaszewska D. (red.), PWN, Warszawa.

\section{Wykaz skrótów}

CzK - „Czerwony Kos”

SDor. - Słownik języka polskiego, red. W. Doroszewski

SMSŻ - „Swawolna Myśl - Swawolne Żarty”

Szp. - „Szpilki”

WB - „Wesoły Bocian”

WMWŻ - „Wolna Myśl - Wolne Żarty” 